\title{
Effect of preoperative gabapentin on intraoperative and postoperative pain in pediatric urogenital surgeries: a randomized controlled trial
}

\author{
Samridhi Nanda*, MD, Chandni Sinha\#, MD, Ajeet Sinha, MD\# \\ *Department of Anaesthesia, Sawai Man Singh Medical College, Jaipur \\ \# Department of Anaesthesia, AllMS, Patna
}

\section{Introduction-}

Gabapentin is extensively used in chronic pain setting, but less often used in acute postoperative pain setting. Our aim was to determine the effect of Gabapentin on acute postoperative pain in pediatric patients.

\section{Objective-}

The aim of the study was to evaluate the effect of $15 \mathrm{mg} / \mathrm{kg}$ Gabapentin on the postoperative pain in pediatric patients 8 to 16 years old posted for urogenital surgeries.

Primary objective - effectiveness of preoperative gabapentin on the postoperative analgesic requirement

Secondary objective-

- To evaluate the intraoperative analgesic requirement

- To evaluate adverse effects like nausea, vomiting, respiratory depression

\section{Methods-}

Single centre, prospective, randomized controlled trial

After approval by the Institutional Ethical Committee and obtaining a written, informed consent, 60 patients of ages 8 to 16 years, scheduled for urogenital elective surgeries were randomly allocated to 2 groups

Group I patients were given $15 \mathrm{mg} / \mathrm{kg}$ of Gabapentin in $5 \mathrm{ml}$ of pl milk and Group II were given $5 \mathrm{ml}$ of milk 2 hours prior to surgery

Patients were induced with injection Propofol $(2 \mathrm{mg} / \mathrm{kg})$, Vecuronium $(0.1 \mathrm{mg} / \mathrm{kg})$, Fentanyl (2 mic/kg); maintained on air + sevoflurane

Postoperatively, the patients were given $(0.5 \mathrm{mic} / \mathrm{kg})$ Fentanyl boluses and $15 \mathrm{mg} / \mathrm{kg}$ of Paracetamol suppository until the $\mathrm{NRS}<3$ or the Respiratory Rate fell to $<12$

A resident blinded to the drug administration assessed Pain score on NRS scale, Sedation on Ramsay Sedation Scale at $0,1,4,8,16,24,32,42,48$ hrs.

Qualitative data was analyzed using Chi-Square t- test For Quantitative data Unpaired t- test was used
Results-

The patient demographics (age, sex, weight) were comparable.

\begin{tabular}{|c|c|c|c|c|}
\hline $\begin{array}{l}S . \\
\text { N } \\
0\end{array}$ & Variable & I & II & P value \\
\hline 1 & $\begin{array}{l}\text { Intraop } \\
\text { fentanyl } \\
\text { bolus } \\
\text { (ug/kg) }\end{array}$ & $\begin{array}{l}0.733 \\
\pm 0.47\end{array}$ & $\begin{array}{c}1.216 \\
\pm 0.5112\end{array}$ & 0.0003 \\
\hline 2 & $\begin{array}{l}\text { Postop } \\
\text { fentanyl } \\
\text { bolus } \\
\text { (ug/kg) }\end{array}$ & $\begin{array}{c}0.916 \\
\pm 0.343\end{array}$ & $\begin{array}{c}1.333 \\
\pm 0.4887\end{array}$ & 0.0003 \\
\hline 3 & $\begin{array}{c}\text { Time of first } \\
\text { analgesic } \\
\text { requirement } \\
\text { (hrs) }\end{array}$ & $\begin{array}{l}6.033 \\
\pm 1.70\end{array}$ & $\begin{array}{l}3.866 \\
\pm 0.76\end{array}$ & 0.0001 \\
\hline
\end{tabular}

Table 1. Analgesic Requirement

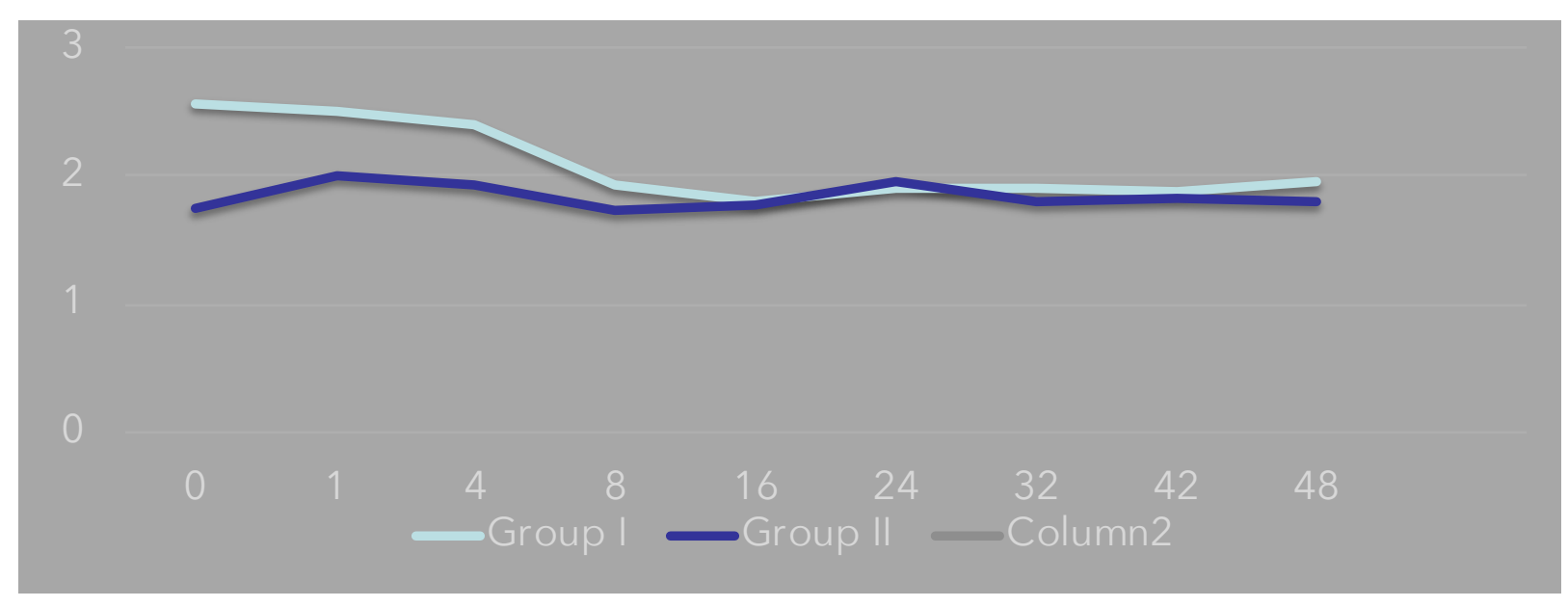

Figure 1. Chart depicting the Ramsay Sedation Score in the Group I,II

None of the patients reported nausea, vomiting, respiratory depression in either groups

\section{Discussion-}

Gabapentin, a GABA analog is a voltage gated calcium channel blocker and also increases GABA concentration. The exact mechanism with which it causes analgesia is yet to be known. The Gabapentin group shows statistically significant difference in the requirement of intraoperative, postoperative analgesic requirement and also the need for analgesia was also significantly delayed in the Gabapentin group (Group I). The findings of the study may be due to the analgesic effect conferred by Gabapentin. Our results complied with some of the previously done studies ${ }^{1,2}$. The limitations of our study was the small sample size,

\section{Conclusion-}

Preoperative administration of Gabapentin reduces the postoperative analgesic requirement in children posted for elective urogenital surgeries.

\section{References-}

1. Choudhry DK, Brenn BR, Sacks K, Shah S (2017) Evaluation of gabapentin and clonidine use in children following spinal fusion surgery for idiopathic scoliosis: a retrospective review. J Pediatr Orthop

2. Mayell A, Srinivasan I, Campbell F, Peliowski A (2014) Analgesic effects of gabapentin after scoliosis surgery in children: a 